\title{
The Impact of Innovative Capabilities and Innovation Types on the Financial Performances of Insurance Companies
}

\author{
Tanja Kamenjarska, Faculty of Economics, Ss. Cyril and Methodius University, Skopje, Macedonia \\ Mario Spremić, Faculty of Economics and Business, University of Zagreb, Croatia \\ (iD) https://orcid.org/0000-0001-8114-0213
}

Ivan Miloloža, Faculty of Dental Medicine and Health, University of Osijek, Croatia

\begin{abstract}
The ability to innovate is essential for achieving a competitive position, and digital innovations have become one of the main drivers of competitive advantage. The factors that affect the degree of innovation (innovation efforts, competitive priorities, market strategy, the internal organisational atmosphere) impact the financial performance of insurance companies considering the market conditions. In order to shed some light on that research gap in post-transition countries, survey research has been conducted on a sample of insurance companies in the Republic of North Macedonia. The results obtained from the structural equation modelling analysis, which seeks to determine the structural relationship between the measured variables and the latent constructions, reveal positive effects of innovation performance on the profitability of insurance companies.
\end{abstract}

\section{KEYWORDS}

Digital Innovations, Digital Transformation, Financial Performance, Innovation Capabilities, Innovation, Insurance Companies, Republic of North Macedonia

\section{INTRODUCTION}

Insurance is a complex mechanism that plays an essential role in every economy. Insurance is a mechanism by which the risk of loss or damage on the part of the insured is transferred to the insurer in exchange for a known amount in advance (premium). Insurance as a social protection mechanism mitigates the effects of exogenous events such as illness, death, and natural disasters. It allows individuals to recover from a sudden accident by relieving or at least limiting the financial burden. The ability to innovate or continuously transform knowledge and ideas into new products, processes, and systems for the benefit of the firm and stakeholders enables firms to secure and maintain a competitive advantage in the marketplace. To motivate employees to be prepared to share knowledge within the organization, the concept of knowledge sharing is a vital component when developing the business model of the company (Jerman, 2020; Ardimento et al., 2013).

The selection of appropriate types of innovations that are analysed below can improve the financial performance of insurance companies and provide a timely response to the needs and desires of the client. The company can introduce a new product with additional functionalities in the insurance industry, such as an additional bonus or benefits (for example, tourist trips abroad). Such innovation

DOI: 10.4018/IJESMA.289634

This article published as an Open Access article distributed under the terms of the Creative Commons Attribution License (http://creativecommons.org/licenses/by/4.0/) which permits unrestricted use, distribution, and production in any medium, provided the author of the original work and original publication source are properly credited. 
can be called product innovation. On the other hand, the company can develop an internal claims handling process or call centre to speed up the delivery process, which can be considered an innovation. The economic effect of innovation can become the starting point for a model for assessing innovation in financial institutions, including insurance companies. Since the institutional arrangements are heavy, the new enterprises encounter difficulties in breaking the institutional elements that prevent the introduction and diffusion of service innovations. This is especially true in the healthcare sector (Wallin, 2017).

Although insurance companies play a crucial role, there are also insurance-related institutions within the sector, such as institutions, to support the implementation of insurance-related operations. Implementing innovative activities in each of these institutions can impact the level of innovation in the entire sector and consequently on economic development. Most insurance companies are focused on improving legacy systems, products, processes, and business models, while not allocating sufficient resources for innovation that could differentiate them in the increasingly present consumer-oriented economy (Deloitte, 2019). Innovation management and digitalisation put pressure on the insurance industry to tailor products and services and simultaneously make them available for use across multiple platforms. Substantially changing the way businesses operate and securing the value of insurance companies becomes a necessity for ensuring financial stability in the long run. Innovation is not immune to the social changes that are primarily caused by the development of humanity through the prism of technological progress and are in itself a variable category.

Frequent changes and updates of regulations in the insurance industry make it constantly relevant as one of the essential pillars for ensuring economic stability. Innovation capacity is a facilitating factor for the rapid introduction of a new product, the adoption of new systems, but also in the face of current competition. Insurance companies need to allocate adequate resources for research in innovation, which could improve the penetration of insurance in the Republic of North Macedonia. To ensure that the planning of the innovation scenario process will be successful, insurance companies need to involve stakeholders such as employees and policyholders in introducing innovation in the organisation and hiring expert consultants.

From here arises the aim of the research to focus on the factors that affect the degree of innovation and their impact on the financial performance of insurance companies in the Republic of North Macedonia. It further discusses the importance and the main changes that companies should consider to enhance their competitive advantage and consequently increase financial performance. The insurance sector in the Republic of North Macedonia has been significantly growing, but still, it is considered a developing market. North Macedonia has been chosen as a representative post-transition country due to the lack of research conducted in this area and the existing gap in the literature where this research attempts to fill as a pioneering work. Analogously, the research questions are set as follows: (i) RQ1: What is the current level of innovation and which types of innovation capabilities introduced in the insurance companies?; (ii) RQ2: How do these innovations affect the financial performance of the insurance companies?

On that note, this paper is organised into six sections. The first section elaborates the topic, the research's importance, and its professional and scientific justification. Furthermore, the subject, the purpose of the research and the plan of presenting the research matter are introduced. The second section aims to provide a detailed review of the available and relevant literature, including the conducted theoretical and empirical research in the insurance innovation industry, to connect the research matter and justify the hypotheses. The third section focuses on gaining insight and an idea of the level of development of the Macedonian insurance industry, where a comparative analysis is conducted of the key indicators such as penetration and density rates. The fourth section aims to elaborate on the scientific justification and the need for research in innovation in insurance companies. Based on the previous theoretical and empirical research, the hypotheses and the conceptual framework are formulated and presented in this section. The fifth section presents the methodological approach of the research and the econometric model used to determine the innovative factors that affect the 
financial performance of insurance companies in the Republic of North Macedonia and their degree of influence. After a detailed explanation of the variables, the population and the sample used in the research, this section provides a systematic overview of the collection of data and methods used. The sixth section presents the research results and provides and aims to present the findings from the collected and analysed data and identify potential managerial implications, challenges and strategies for implementing innovations. Finally, conclusions are drawn, including the limitations and directions for future research.

\section{Background}

Most studies investigate the relationship between innovation types and innovation performance, mainly in the manufacturing sector (Gunday et al., 2011; Kalay \& Lynn, 2015). Studies related to the service sector often determine the relationship between the company's business strategies and innovative activities (Lilly \& Juma, 2014; Akman \& Yilmaz, 2008). On the other hand, most research focuses on firms' innovation capability and performance (Huhtala et al., 2014; Chang et al., 2012a; Taherparvar et al., 2014). Given the fact that there is a lack of research examining the relationship between innovation capability, types of innovation and financial performance of insurance companies, this paper aims to establish a more outstanding balance and empirically-based picture of innovation activities in the service sector, with a particular emphasis of the insurance industry.

Insurance innovations are related to the product, market, process, or organisation (Deloitte, 2012; Schaerer et al., 2011). In that manner, the paper adopts the four-dimensional service sector-related innovation model proposed by Howells et al. (2004), Kuusisto \& Meyer (2002), OECD (2005), Oke (2007), and Tether et al. (2002). Innovative insurance products with features that reduce moral hazard, adverse selection, fraud and also reduce monitoring and administration costs have the potential to increase access to insurance for smallholders. Some studies examine unique types of innovation, such as process innovation (Abrunhosa \& Moura E Sá, 2008) or product innovation (Prajogo \& Sohal, 2004), while others explore the process and product innovation (Martinez-Costa \& Martinez-Lorente, 2008).

On the other hand, many studies conceptualise innovation and link it to marketing and organisational innovation (Evangelista \& Vezzani, 2010; Gunday et al., 2011; Chang et al., 2012b). In this regard, Atlay et al. (2013) analyse the relationship between innovation and firm performance. The findings of their study show that technological innovation has a significant positive impact on firm performance. Still, no evidence of a significant and positive relationship between non-technological innovation and firm performance has been found. Organisational innovation itself impacts business performance in terms of productivity, duration, quality, and flexibility (Armbruster et al., 2008).

Although innovation is considered a vital determinant of a firm's performance, it remains unclear how marketing affects innovation performance (Reibstein et al., 2009). Most of the literature on innovation management is devoted to analysing product innovation (Taylor, 2010; Turner et al., 2010). Following the interpretations of Polder et al. (2010), it is proved that "product and process innovations lead to greater productivity only when performed in conjunction with organisational innovation", but also many researchers stress that product and process changes cannot be easily separated and often take place together (Pejic Bach, 2014). It is known that one of the biggest microprocessors in which such a co-evolutionary relationship between product innovation and capability development is based in the knowledge processes (Grant, 1996). In essence, there is a strong correlation between knowledge processes and skills development in firms (Kashan \& Mohannak, 2014; Lichtenthaler \& Lichtenthaler, 2009; Tippmann et al., 2013) and empirical (Lupton \& Beamish, 2014; Subramaniam \& Venkatraman, 2001). Most studies investigate the relationship between innovation types and innovation performance, mainly in the manufacturing sector (Gunday et al., 2011; Kalay \& Lynn, 2015). Studies related to the service sector often determine the relationship between the company's business strategies and innovative activities (Lilly \& Juma, 2014; Akman \& Yilmaz, 2008). On the other hand, most research focuses on firms' innovation capability and performance (Huhtala et al., 2014; Chang et al., 2012b; Taherparvar et al., 2014). Although there are various studies on innovation 
and performance, there is a lack of research on the ability of organisational innovation. Hence, there is still a need to develop more comprehensive frameworks for measuring the effects of organisational innovation capability.

Technological innovation is an essential source for growth and market leadership and can be a prominent advantage for many organisations. The ability of an organisation to innovate is a prerequisite for the successful use of innovative resources and new technologies. Accordingly, Lazonick's theory of the innovative enterprise focuses on how strategy and structure determine the competitive advantage of the business enterprise (Lazonick, 2005). The essence of the innovative enterprise, according to the author, deals with organisational integration based on skills that can be included in collective and cumulative learning. Lazonick (2005) emphasises the importance of organisational and management processes as essential elements that support firms and innovative performance. Innovative performance has positive effects on the product, market and financial performance of the company. These firms are associated with increased sales and market share because they contribute significantly to the satisfaction of existing customers and acquiring new ones. Organisations are increasing interest in introducing ICT due to its prominent role in various administrative aspects in companies and significant gains in reducing the cost of production processes, improving price levels, increasing speed and quality improvement. The study by García-Muiña \& Navas-López (2007) analyses the relationship between technological capabilities and company success. It is observed that technological capabilities significantly affect the success of the company. Several studies analyse the relationship between ICT strategies and firm performance. Burke (2010) explained that ICT is a critical determinant in explaining increased sales volume and the ability to acquire new customers, while information and technology communication boost financial development (Alshubiri et al., 2019). The financial technology is considered as crucial factor for company's success due to its many benefits varying from technical advancement, enterprises innovation, the need for reducing costs, and for improving the relationship with the customers (Marrara et al.2019). Similarly, by introducing digital transformation in companies, the opportunity for developing a business model based on provision of services which is in the same time customer concentrated, significantly increases (Bagnoli et al., 2019). But it is important to note that when aiming to accomplish business concepts that lead to business transformation, there is no single, one right combination of technical concepts that can be clearly determined (Furjan et al., 2020), or as (Susa Vugrec et al., 2017) note, it is unfeasible to discover a 'perfect' mechanism to implement IT governance, because there is no unique formula for what IT governance should look like. To achieve an effective and successful digital transformation process, it is from major importance to develop a clear and focused digital transformation strategy (Pejić Bach, 2018).

Further, Kamal \& Qureshi (2009) found a positive relationship between ICT use and growth, development and sustainability of small and medium enterprises. The positive impact of ICT on the business performance of small and medium enterprises is widely established in a significant number of empirical studies. ICT is the catalyst of organisational change and is a facilitator for improving the business performance of small and medium enterprises. Empirical findings obtained from the study conducted by Frank \& Wallace (2012) indicate a positive impact of ICT on the survival of young and medium-sized companies. Today's business environment is very dynamic and rapid changes due to technological innovation, increased awareness and demand from customers. Applying concepts, techniques, policies and strategies for implementing ICT in insurance companies is a prerequisite for local and global market competitiveness. ICT changes the way insurance companies operate; it has a significant impact on their corporate relations and the variety of innovative devices available to improve service speed and quality. By introducing digital technology, the organisation faces cultural change, which positively affects the ability to endure the dynamic changes in the market (Corejova et al., 2020). The inclusion of new systems and ICT facilitates business planning and encourages production development and execution, stimulating process and product control (Vargas et al., 2015). In addition, ICT can also directly impact innovation-based ICT business products, processes, and 
services and on business models (Brynjolfsson \& Saunders, 2010). The issue faced by the existing financial industry is that when introducing an innovation, the overall competition increases in a race of exploring innovations that will enhance future customer satisfaction, which is why the concept of traditional banking is obsolete and ineffective (Martinčević et al., 2020). In this direction, innovation is a strategic variable because it allows companies to differentiate their products, services and production processes concerning their competitors.

\section{COMPARATIVE ANALYSIS OF THE SELECTED COUNTRIES}

Despite the observed growth of the insurance industry in the Republic of North Macedonia, this market is in the development phase. It is far from the levels attained in the insurance markets in developed economies. To better understand the current level of development of the insurance industry in the Republic of North Macedonia, the penetration and density rates of the insurance industry are analysed as the leading indicators for determining the operating performances of the market. The penetration rate estimates the contribution of gross written premium (GWP) to a country's gross domestic product (GDP). This rate in the Republic of North Macedonia is $1.52 \%$ in 2019 and is lower than the countries analysed in Figure 1. For instance, Slovenia (5.05\%), Slovakia (2.21\%), Croatia (2.64\%), Serbia (1.93\%), Czech Republic (2.83\%), Bulgaria (2.42\%), Netherlands (9.22\%), Austria $(4.42 \%)$ have higher penetration rates, while the world average penetration rate $(7.23 \%)$ is more than four times higher than in the Republic of North Macedonia.

Figure 1. Insurance penetration and density rates in selected countries (2019) (Source: ISA (2020), Swiss Re (2020))

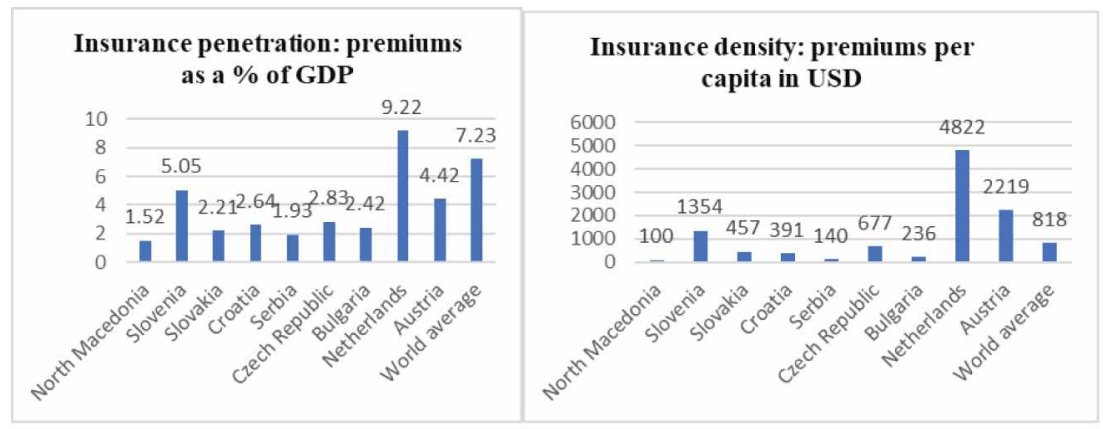

The density rate is calculated as the ratio between the gross written premium (GWP) and the number of inhabitants in the country. It presents the gross written premium (GWP) per capita. This rate in the Republic of North Macedonia (\$100 in 2019) is significantly lower relative to the selected and analysed countries (Slovenia \$1354, Slovakia \$457, Croatia \$391, Serbia \$140, Czech Republic \$677, Bulgaria \$236, Netherlands \$4822, Austria \$2219, World average \$818). Consequently, the leading causes for the current development phase of the insurance industry in the Republic of North Macedonia are the insubstantial overall awareness, low insurance culture, and the absence of information among the population regarding the broad spectrum of benefits offered by the insurance.

Following the Law on Compulsory Traffic Insurance (2008), every owner and user of a motor vehicle is obliged to acquire a third-party motor liability (MTPL) insurance policy. As a result, this insurance class has the highest share in the total GWP in the Republic of North Macedonia (43.45\% in 2018 and $43.25 \%$ in 2019). The second most common class is property insurance in the Republic of North Macedonia, with a share of $17.31 \%$ in 2018 and $16.75 \%$ in 2019, and the share of the life insurance class is $16.8 \%$ in 2018 and $17.3 \%$ in 2019 in the total GWP (Figure 2). This implies that the 
country's insurance is often regarded as an expensive, luxury, and nonessential product rather than an investment for a safe future. To increase the levels of awareness amongst the potential clients, the insurance companies operating in the Republic of North Macedonia ought to put additional focus on the development of innovative channels of distribution of optional insurance classes for consumer orientation, introducing new products and enhance existing and implement educational campaigns to better the insight of the benefits offered by the insurance (Gockov \& Kamenjarska, 2021).

Figure 2. Structure of GWP by insurance class (2018-2019) in the Republic of North Macedonia (Source: Insurance Supervision Agency (2020))

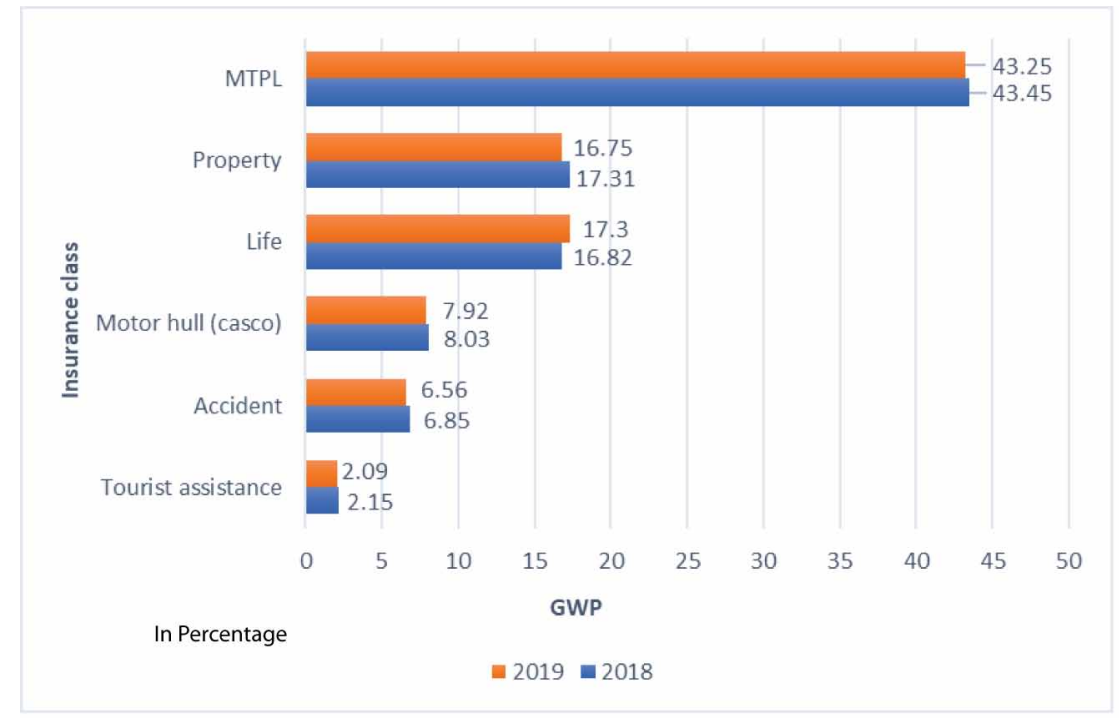

The insurance profitability trends assessed by the return on equity (ROE) and return on assets (ROA) in the selected countries throughout 2012 to 2017 is exhibited in Figure 3. It can be observed that ROE in the Republic of North Macedonia in 2017 is 6.1\%, which is considerably lower compared to Hungary (22.6\%), Poland (15.6\%), Slovakia (14.5\%), Czech Republic (10.6\%), Latvia (10.6\%), Lithuania (10.5\%), Slovenia (8.6\%). This could result from the relatively high capitalization of the insurance companies operating in the Republic of North Macedonia relating to the underdeveloped insurance market in the country. Furthermore, ROA in 2017 is $2.0 \%$ and it is lower compared to Poland (2.9\%), Slovakia (2.5\%), Latvia (2.4\%), Hungary (2.3\%), Lithuania (2.1\%). Additionally, the noticed decline in ROA in the Czech Republic (1.63\%) and Slovenia (1.74\%) in 2017 relative to 2016 leads to a lower profitability ratio than the Republic of North Macedonia.

These indicators point to the underdeveloped insurance market in the Republic of North Macedonia. Namely, they highlight that the insurance in the country still lags behind the analysed countries in Europe. Through an institutional arrangement of existing and new insurance companies following the developed market economies, creating conditions for the market operation of insurance companies with particular emphasis on the need to develop insurance and reinsurance in the Republic of North Macedonia, creating conditions for insurance development as a significant segment of the economic system and macroeconomic policy and thorough study of the need and the way of educating the population about the need for insurance and the benefits provided by insurance (Jovanovski, 2005), there is a probable possibility for creating conditions for increasing the level of development 
Figure 3. ROE and ROA in the selected countries (2012 - 2017) (Source: ISA (2020), RAEX (2018)). Calculations based on data from the IMF, OECD, Hungarian National Bank, Czech National Bank, The National Bank of Slovakia, Slovak Insurance Association, Slovenian Insurance Supervision Agency, Latvian Insurers Association, Statistics Estonia, Polish Insurance Association, National Bank of the Republic of Belarus and Ministry of Finance of the Republic of Belarus.

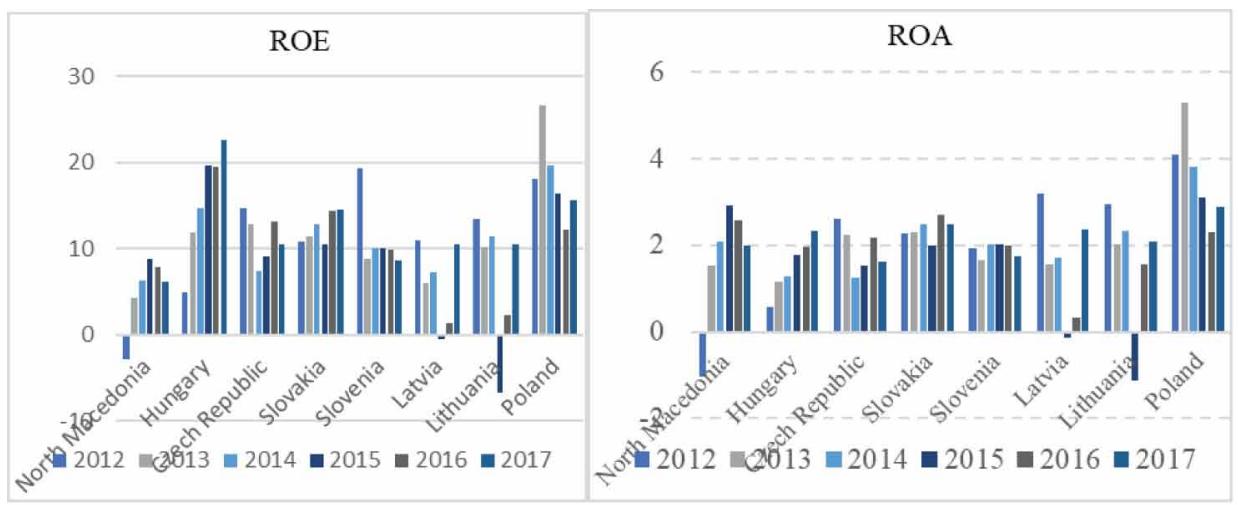

of the insurance market in the country and achieving an eligible competitive position in regional and European framework.

\section{Hypothesis Development and Conceptual Framework}

Although researchers have different definitions of innovating, everyone agrees that innovation ability is a process. In this process, companies acquire and integrate different fields of knowledge to create creative ideas and new products to satisfy customers (Chen \& Xu, 2009). The ability to innovate describes the characteristics that a business needs to support innovative activities. The ability to innovate describes the characteristics that a business needs to support innovative activities. These characteristics enable the business to quickly and successfully adopt new practices and processes and develop and introduce improved products and services to compete more efficiently in the rapidly changing environment (Balan \& Lindsay, 2010a; 2010b). Product innovation is empirically found and conceptually emphasized as a critical factor for developing competitive capabilities in organizations (Danneels, 2002; Eisenhard \& Martin, 2000; Grant, 1996; Slater et al., 2014). Vicente et al. (2015) conceptualized that innovation capability is a solid capacity for new product development through a combination of strategic capability and internal technological processes. It can also be noted that a functional product development process usually involves a cross-functional team that brings together wide variety sources of expertise (Eisenhardt \& Martin, 2000).

In this regard, hypotheses can be defined as:

H1: The ability to innovate has a statistically significant impact on innovation.

H1a: Innovation capacity has a statistically significant impact on product innovation.

H1b: The ability to innovate has a statistically significant impact on process innovation.

H1c: The ability to innovate has a statistically significant impact on organisational innovation.

H1d: The ability to innovate has a statistically significant impact on marketing innovation.

The Oslo Handbook developed by the OECD (2005) describes several aspects that can be used to measure the performance of innovations in the form of output (number of new products produced, improved quality of work) and the impact of innovation (changes in competition, expansion of the market, increased productivity, profit, and environmental impact).

Research conducted by Fontana (2011) described the concept of the three dimensions of innovation performance: internal and social, and commercial performance. Researchers used different 
financial and non-financial indicators to analyse business performance, dividing them into subjective and objective indicators. Yildiz et al. (2014) suggested that innovation has a positive effect on business performance. The innovation process can be seen as an effective driver for improving the organisation's innovation and business performance (Lendel \& Varmus, 2014). Improving the quality of the new product or service, reliability and innovation has resulted in product/service innovations and improved firm performance (Rosli \& Sidek, 2014). Additionally, Wang \& Hsu (2014) researched the high-tech industry in Taiwan to identify links between market orientation, service innovation, and innovation performance. The findings reveal that innovation has a fully mediating effect on innovative performance.

Furthermore, the study suggested that technology-based product quality makes it easier for firms to generate superior performance innovation. Similarly, Mabruk \& Mamogli (2010) research in the banking sector has shown that product innovation improves profitability, while process innovation improves profitability and efficiency. On the other hand, numerous studies have shown that organisational innovation is positively related to innovative performance (Reed et al., 2012) and helps better understand what type of competencies would affect competitive advantage. In addition, product and process innovations play an influential role in organisational performance.

Numerous studies have found a positive relationship between innovation and firm performance (Wu et al., 2003). Innovation capabilities are integral to various performance indicators relating to new patents, products, projects, processes, and organisational arrangements.

Hence, it is assumed that:

H2: Higher levels of innovations are associated with improved innovation performance.

H2a: Product innovation has a statistically significant impact on innovation performance.

H2b: Process innovation has a statistically significant impact on innovation performance.

H2c: Organisational innovation has a statistically significant impact on innovation performance.

H2d: Marketing innovations have a statistically significant impact on innovation performance.

Numerous studies focusing on the innovation-performance relationship establish a positive relationship between innovation and company performance (Olson \& Schwab, 2000; Hult \& Ketchen, 2001; Calantone et al., 2002; Garg et al., 2003; Wu et al., 2003). Process and product innovations are the most common types of innovation being examined. Many of these studies accept a more or less positive relationship between innovation and company performance, but some suggest a negative or insignificant relationship (Subramanian \& Nilakanta, 1996). Focusing on innovative activities and the role of investment in research and development, Branzei \& Vertinsky (2006) highlighted their positive impact on the overall growth, success and survival of the firm, while Bigliardi \& Dormio (2009) identified innovation as the primary driver of companies, for prosperity, growth and maintaining high profitability. Similarly, Markez \& Fereira (2009) have shown how successful innovation activity helps establish a firm's favourable competitive position, resulting in competitive advantage and improved performance.

Other studies (Thornhill, 2006) also suggest that firms benefit from innovation. However, Santos et al. (2014) did not find a significant relationship between innovation and financial performance, while Silva et al. (2017) empirically showed that market innovation and strategic export performance are negatively correlated in the context of international business. In this regard, it is expected that:

H3: Innovation performance has a statistically significant impact on financial performance.

Based on the results analysed from the theoretical and empirical research of the existing literature, Figure 3 presents the research framework that presents the proposed relationship between innovation and financial performance of insurance companies and the hypotheses related to these variables. 
The conceptual framework proposes four different types of innovation implemented in insurance companies that are assumed to have a statistically significant impact on innovation performance and result in positive financial performance.

\section{Figure 4. Conceptual framework and hypotheses (Source: author's elaboration)}

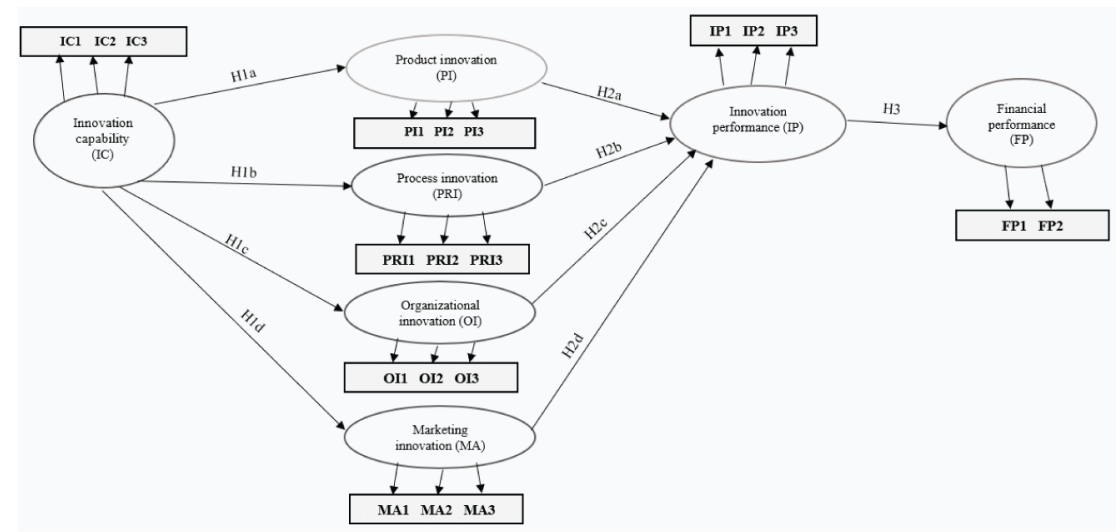

This conceptual framework has been designed upon thorough literature review and enhanced over the years to be widely used in the research relating to innovation in organisations. Suppose the firm can identify new and innovative approaches and ideas and further reshape them into enhanced products, services or processes. In that case, it will develop a capacity to replace the techniques, equipment and software used with improved ones.

Furthermore, this capacity is expected to enable firms to implement new organisational methods. These marketing methods are significantly distinguishable from the existing ones used by the enterprise, improve the existing business practices, strengthen the external relations, and introduce new ways of solving the business problems. All of the four types of innovation, if appropriately managed, are expected to enhance the firm's financial health and efficiently achieve the set financial objectives.

\section{METHODOLOGY}

To empirically investigate which are the main drivers of innovation in insurance companies in the Republic of North Macedonia and what is the impact of innovation capabilities on financial performance, primary data sources were used, which were obtained through a structured questionnaire that was distributed over two weeks with the help of field assistants and associates. According to the opportunities of reaching the potential respondents, the questionnaire was administered online and on paper.

Because the research subject is somewhat complex, the questionnaire was distributed to the Board of directors, middle-level management and employees in the insurance companies with more than ten years of work experience in the sector who have a solid knowledge of current and previous organisational practice in various functional areas, processes and strategies of the insurance companybecause employees with more extended work experience have a higher probability of being included in the implemented innovation processes during their career. As a limitation of the research, the total number of employees in 2020 in the insurance companies is 1874 . Still, it is somewhat subjective to estimate the number of employees with more than ten years of work experience due to the lack of official data. To make the sample more relevant and representative, employees with experience in 
implementing innovation processes were included. The target population as predefined was elaborated in detail to the field assistants and associates, and each respondent had an equal chance of being selected. The importance of the research was elaborated on to each respondent. They were encouraged to provide truthful and faithful answers to preserve the objectivity and reliability of the research. The questionnaires sent to the respondents contained a brief explanation stating the purpose of the research, the significance of the respondents' participation, a guaranteeing statement of confidentiality of the answers and a gratitude statement.

The questionnaire was self-administered as this type of questionnaire is accessible to distribution and economical. It includes 21 individual questions designed upon thorough literature review (research instrument is explained in Table 6 in the Appendix) to assess the insurance company's business strategy, innovation efforts, competitive priorities, internal organisational atmosphere, market conditions, and financial performance. Adopting a suitable technique for data collection and after the screening and cleaning the data from the answers to the questionnaires, a sample of 128 respondents was collected. The research sample included 16 insurance companies operating in the Republic of North Macedonia (5 life and 11 non-life insurance companies). From those, a random sample of respondents was obtained considering that the questionnaire was distributed with the help of experienced associates and field assistants who possess the knowledge of selecting relevant respondents according to the instructions provided and their professional expertise in conducting surveys, meaning that each individual had an equal chance of being selected. The questions were short, concise and clear. Respondents were asked to rate the innovative activities that were available and implemented in their companies in the last three years on a Likert scale from 1 to 5 (1 - not implemented, 2 - imitated by national market, 3 - imitated by the international market, 4 - improved current production/process/marketing / organisational practice, 5 - original product/process/marketing / organisational practice developed).

The questions were developed after a detailed review of the literature related to innovation and financial performance in organisations, as presented in Table 6 in the Appendix. The innovation measures for each type of innovation are designed based on the theoretical and operational definitions and aspects of the literature explained in the OECD Oslo Handbook (2005) regarding the four types of innovation and approach to measuring service innovation activities. The obtained data was coded and inspected. Thus any deviations or any other variations in the data set were removed. The answers were analysed using the statistical software IBM SPSS 23, Stata and IBM SPSS AMOS 24. The research profoundly focuses on the insurance industry in the Republic of North Macedonia since this market is still emerging, as observed in the analysis conducted in Table 5 in the Appendix. Since insufficient effort was made to examine the relationship between the types of innovation and financial performances in the insurance companies in the country, there is a need to conduct detailed research where this research steps as a pioneering work. Namely, for investors, shareholders, employees, insurers and associations, the research is expected to yield information that will provide valuable recommendations for improving services and processes in the insurance companies.

\section{RESULTS AND DISCUSSION}

The validity of the constructions was measured using the Bartlett sphericity test and the KaiserMayer-Olkin measure (KMO) for sampling adequacy of individual variables (Rajapathirana \& Hui, 2018). The total KMO score is considered valid with a value of 0.6 or more to conduct factor analysis (Özdamar, 2017). The Bartlett and KMO sphericity test (0.815) found that the data set was suitable for factor analysis (Table 1). The explained cumulative variance is $70.053 \%$, which exceeds the acceptable limit of $60 \%$ (Özdamar, 2017). The Bartlett sphericity test indicates a sufficient correlation between the variables with a value of 1395,928 , which is significant for $\mathrm{p}<0.001$. The factor load on each scale exceeds 0.5 (Ringle et al., 2015), and thus these values indicate that the measurements have an acceptable convergent validity. The obtained values show that the scales used in the research are valid (Table 1). 
Table 1. Kaiser-Mayer-Olkin (KMO) and Bartlett test

\begin{tabular}{|l|l|}
\hline KMO Bartlett's test & 0.815 \\
\hline Kaiser-Mayer-Olkin (KMO) measures of sampling adequacy & 1395.928 \\
\hline Bartlett's Test of Sphericity & 190 \\
\hline Approx. chi-square & 0.000 \\
\hline Df & \\
\hline Sig. & \\
\hline
\end{tabular}

Source: Author's calculations

Furthermore, security measures or the degree of internal consistency are assessed by loading on factors of items having an acceptable value of 0.70 and a Cronbach $\alpha$ value of 0.7 and above (Ringle et al., 2015). The reliability coefficient was tested using Cronbach $\alpha$ to measure the reliability of a set of two or more structures. According to the test results, the total safety scales for seven factors range from 0.727 to 0.863 (Table 2) and exceed the 0.7 thresholds introduced by Nunnally (1978). The validity of construction "assesses the extent to which measurement represents and logically relates the observed phenomenon to construction through basic theory" (Fornell \& Larcker, 1981).

Construct reliability (Composite reliability - CR) and derived mean-variance (AVE) were used as convergent validity measures (Fornell \& Larcker, 1981). Convergent validity was achieved because the values of $\mathrm{AVE}$ and CR are higher than the minimum thresholds of 0.50 and 0.70 (Fornell \& Larcker, 1981; Ringle et al., 2015). Some authors believe that CR must reach a value of 0.6 or more (Fornell $\&$ Larcker, 1981). Financial performance was around 0.947, which is higher than other constructions of the scale: innovation capability (0.894), marketing innovation (0.926), organizational innovation $(0.822)$, process innovation $(0.864)$, product innovation $(0.869)$, innovative performance $(0.878)$. The results also indicated that all latent variables reached a reference value of 0.7 (Nunnally \& Bernstein, 1994) (Table 2).

Regarding AVE, all constructions exceed the proposed value of 0.5 (Bagozzi \& Yi, 1988), i.e. they range from 0.611 to 0.900 , which indicates that the measure has adequate convergent validity. Finally, the measurement model showed adequate reliability, convergent and discriminatory validity.

The relationship between latent variables is a complex network of associations where there are mediating effects of some types of innovation on the relationship innovation - financial performance. To detect possible mediations, we could conduct more hierarchical regression analyses following the procedure developed by Baron \& Kenny (1986), but due to the complexity and diversity of mediating effects, to discover the best structure of complex relationships between the analysed variables, the implementation of the SEM approach is preferred. This procedure gains weights, loads, and path estimation when performing a repetitive pattern of multiple regressions until the solution fits into a set of weights used to estimate the results of latent variables. This approach was also chosen because of its ability to test random relationships between structures with multiple measurement elements.

Hence, the SEM analysis was performed in one step, simultaneously assessing the measurement and structural models in IBM SPSS AMOS 24. The results consistently support the factor structure for all factors in the PCA phase. The structured model of SEM investigates the impacts of different types of innovations on the financial performance of insurance companies and proposes a theoretical scheme for such a network of relationships as presented in Figure 3, which is also a conceptual framework of the research.

The structured model is also supported by appropriateness indices (Table 3). Adequacy indices include the Comparative Fit Index (CFI; Bentler, 1990), the Normative Fit Index (NFI; Bentler-Bonett, 1980), the Relative Fit Index (RFI; Bollen, 1986), the Increase Fit Index (IFI; Bollen, 1989b) and the Tucker-Lewis index (TLI; Bentler \& Bonett, 1980). All these indices indicate a perfect fit when 
Table 2. Test for the degree of internal consistency and convergent validity

\begin{tabular}{|c|c|c|c|c|c|}
\hline Factors & Items & $\begin{array}{l}\text { Factor } \\
\text { loads }\end{array}$ & Cronbach $\alpha$ & AVE & CR \\
\hline $\begin{array}{l}\text { Innovation } \\
\text { Capability } \\
\text { (IC) }\end{array}$ & $\begin{array}{l}\text { Organisational culture } \\
\text { Using knowledge from different sources } \\
\text { Involvement of employees and customers }\end{array}$ & $\begin{array}{l}0.846 \\
0.904 \\
0.828\end{array}$ & 0.858 & 0.739 & 0.894 \\
\hline $\begin{array}{l}\text { Product } \\
\text { innovation } \\
(\mathrm{PRI})\end{array}$ & $\begin{array}{l}\text { Increasing the quality of production in the } \\
\text { components or materials of current products/services } \\
\text { Reduction of production costs of components or } \\
\text { materials of current products/services } \\
\text { Development of innovations in current products/ } \\
\text { services that lead to improved customer satisfaction } \\
\text { and access }\end{array}$ & $\begin{array}{l}0.816 \\
0.823 \\
0.853\end{array}$ & 0.857 & 0.690 & 0.869 \\
\hline $\begin{array}{l}\text { Process } \\
\text { innovation } \\
(\mathrm{PCI})\end{array}$ & $\begin{array}{l}\text { Identify and eliminate activities that do not add } \\
\text { value in the process of selling and paying damages } \\
\text { Reduce the price and increase the speed of service } \\
\text { delivery } \\
\text { Increasing the quality of the sales process }\end{array}$ & $\begin{array}{l}0.818 \\
0.938 \\
0.707\end{array}$ & 0.855 & 0.682 & 0.864 \\
\hline $\begin{array}{l}\text { Organizational } \\
\text { innovation }(\mathrm{OI})\end{array}$ & $\begin{array}{l}\text { Renewal of the organisational structure for the easier } \\
\text { formation of strategic partnerships and long-term } \\
\text { business collaborations, facilitation of teamwork and } \\
\text { coordination between different departments } \\
\text { Update on quality management systems, human } \\
\text { resources and information system management and } \\
\text { information sharing practices } \\
\text { Renewal of routines, procedures and processes }\end{array}$ & $\begin{array}{l}0.765 \\
0.912 \\
0.647\end{array}$ & 0.864 & 0.611 & 0.822 \\
\hline $\begin{array}{l}\text { Market } \\
\text { innovation } \\
\text { (MI) }\end{array}$ & $\begin{array}{l}\text { Renovation of the design of current and/or new } \\
\text { products/services through changes in appearance, } \\
\text { packaging or shape, without changing their essential } \\
\text { technical and functional characteristics } \\
\text { Renewal of distribution channels without change } \\
\text { of logistics, processes related to the delivery of the } \\
\text { product/service } \\
\text { Update of promotion and pricing techniques for the } \\
\text { product/service used to promote current and/or new } \\
\text { products/services }\end{array}$ & $\begin{array}{l}0.854 \\
0.892 \\
0.949\end{array}$ & 0.727 & 0.808 & 0.926 \\
\hline $\begin{array}{l}\text { Innovation } \\
\text { performance } \\
\text { (IP) }\end{array}$ & $\begin{array}{l}\text { Ability to introduce new products and services to the } \\
\text { market before competitors } \\
\text { Introduced innovations in work processes and } \\
\text { methods } \\
\text { Improved quality of new products and services }\end{array}$ & $\begin{array}{l}0.744 \\
0.858 \\
0.915\end{array}$ & 0.853 & 0.708 & 0.878 \\
\hline $\begin{array}{l}\text { Financial } \\
\text { performance } \\
(\mathrm{FP})\end{array}$ & $\begin{array}{l}\text { ROA } \\
\text { ROE }\end{array}$ & $\begin{array}{l}0.952 \\
0.946\end{array}$ & 0.782 & 0.900 & 0.947 \\
\hline
\end{tabular}

Source: Author's calculations

close to 1 . Brown \& Kadek (1993) found that a value of about 0.08 or less for the root mean square approximation error (RMSEA) would indicate a reasonable approximation error. On the other hand, $\mathrm{Hu} \&$ Bentler (1999) suggest that, for continuous data, RMSEA $<0.08$, TLI $<0.95$, CFI $<0.95$ are necessary values for model fit. The comparative fit index (CFI) exceeded the recommended breakout level of 0.9 (Bagozzi \& Yi, 1988). The root means square approximation error (RMSEA) is in line with the cross-sectional level of 0.08 recommended by Brown \& Kadek (1993). The combination of these results suggested that the measurement model showed a good level of suitability. These indices 
are shown in Table 3, and they showed a moderate but acceptable level of overall model adequacy and therefore provided support for the overall validity of the structural model.

Table 3. Goodness-of-fit indices

\begin{tabular}{|l|l|l|}
\hline \multicolumn{1}{|c|}{ Goodness-of-fit indices } & \multicolumn{1}{c|}{ Construct } & \multicolumn{1}{c|}{ Reference value } \\
\hline Chi2/degree of freedom & 1.865 & $1<\chi 2 / \mathrm{df}<5$ \\
\hline CFI (comparative fit index) & 0.964 & $0,95<\mathrm{CFI}<1$ \\
\hline NFI (normed fit index) & 0.947 & $0,90<\mathrm{NFI}<1$ \\
\hline RFI (relative fit index) & 0.927 & $0,90<\mathrm{RFI}<1$ \\
\hline IFI (incremental fit index) & 0.970 & $0,95<\mathrm{IFI}<1$ \\
\hline TLI (Tucker-Lewis fit index) & 0.955 & $0,95<\mathrm{TLI}<1$ \\
\hline RMSEA (root mean square error) & 0.071 & $\mathrm{RMSEA}<0,08$ \\
\hline
\end{tabular}

Source: Author's calculations

From Table 4, it can be determined through standardised path assessments (SPE) that the ability to innovate has a positive impact on the dimensions of innovation: organisational innovation (0.52), product innovation $(0.58)$, marketing innovation $(0,54)$ and process innovation $(0.28)$. Also, two dimensions of innovation showed a positive relationship with innovation performance: process innovation (0.65) and product innovation (0.16).

However, it was found that process innovations are positively and statistically significant, while product innovations have a positive and statistically insignificant relationship with innovation performance. Furthermore, organisational innovation (-0.072) and marketing innovation (-0.36) negatively affect innovation performance. Additionally, innovation performance $(0.68)$ indicates a positive correlation with the financial performance of insurance companies.

Table 4 shows the standardised path estimates and p-values for the structural model. Consequently, hypotheses that suggest a significant relationship between innovation and performance are supported,

Table 4. Standardised path estimates and hypothesis test

\begin{tabular}{|l|l|l|l|l|l|l|}
\hline \multicolumn{1}{|c|}{ Hypothesis } & \multicolumn{1}{|c|}{ Path } & \multicolumn{1}{c|}{ SPE } & \multicolumn{1}{c|}{ b } & \multicolumn{1}{c|}{ t } & \multicolumn{1}{|c|}{ p } & \multicolumn{1}{c|}{ Result } \\
\hline H1a & IC $\rightarrow$ PR & 0.58 & 0.617286 & 5.40 & 0.000 & Accepted \\
\hline H1b & IC $\rightarrow$ PC & 0.28 & 0.300134 & 2.63 & 0.009 & Accepted \\
\hline H1c & IC $\rightarrow$ OR & 0.52 & 0.534870 & 4.51 & 0.000 & Accepted \\
\hline H1d & IC $\rightarrow$ MA & 0.54 & 0.492284 & 4.42 & 0.000 & Accepted \\
\hline H2a & PR $\rightarrow$ IP & 0.16 & 0.014597 & 0.13 & 0.893 & Rejected \\
\hline H2b & PC $\rightarrow$ IP & 0.65 & 0.594387 & 5.89 & 0.000 & Accepted \\
\hline H2c & OR $\rightarrow$ IP & -0.072 & -0.068901 & -0.59 & 0.545 & Rejected \\
\hline H2d & MA $\rightarrow$ IP & -0.36 & -0.381526 & -2.79 & 0.005 & Accepted \\
\hline H3 & IP $\rightarrow$ FP & 0.68 & 0.427290 & 4.31 & 0.000 & Accepted \\
\hline
\end{tabular}

Source: Author's calculations 
except for two hypotheses ( $\mathrm{H} 2 \mathrm{a}$ and $\mathrm{H} 2 \mathrm{c}$ ). The next step in evaluating the SEM model was to examine the significance of each hypothesised path in the research model. The results of the analysis are presented and summarised in Table 4.

Hypotheses H1a, H1b, H1c, and H1d examined the effects of individual innovation ability factors on the four dimensions of innovation and found that innovation ability was an influential factor in the success of these dimensions, supporting H1a, H1b, H1c, and H1d. Furthermore, organisational innovation has been shown to have a statistically insignificant and negative impact $(\mathrm{H} 2 \mathrm{c})$, while marketing innovation has found a significant and negative relationship to innovation performance $(\mathrm{H} 2 \mathrm{~d})$. In this regard, hypotheses $\mathrm{H} 2 \mathrm{a}$ and $\mathrm{H} 2 \mathrm{c}$ were not supported, and the results showed that organisational innovation and product innovation have no significant relationship with the innovation performance of insurance companies.

The R2 (0.6041) and Adj-R2 (0.5345) for the presented model show that the variables explain $60.41 \%$ or $53.45 \%$ of the variance of the financial performance of the companies. In addition, a direct positive impact of innovation performance on financial performance (H3) was identified, and the most vital driver of this relationship was found to be process innovation (H2b). The positive impact of innovations in processes and products on the innovation performance of insurance companies is in the direction of the results obtained from several types of research. In addition to the result that process innovations and product innovations are positively related to certain aspects of innovation performance, it can be noted that organisational innovations harm companies' innovation performance.

These findings do not correspond to theoretical and empirical research (Lin \& Chen, 2007; Reed et al., 2012) in which a positive and direct impact on innovative performance was found. This is because, in a stable environment, businesses, customers and suppliers have an aversion to change. Therefore, implemented innovative activities in insurance companies can result in a negative impact on performance. Furthermore, the rigidity of the structure and the increased bureaucratic set-up in the organisation can also stifle innovative activities and thus affect the entire industry.

On the other hand, it is a dynamic environment; innovation has a positive role in the performance of the enterprise and change is considered normal. Companies that avoid innovative activities can be eliminated in such an environment, while innovators can maintain a favourable competitive position (Garg et al., 2003). The dynamic environment allows new entrants to be more innovative and entrepreneurial, resulting in increased profitability and growth (Zahra \& Neubaum, 1998). Additionally, the negative impact of the organisational innovation can be a result of the insufficient emphasis on delivering customer-centric insurance services, lack of focus on the primary components of capacity most commonly associated with the human side of performance or implementing inadequate measures for building appropriate capacity for organisational innovation as one of the more matured types of 4-types innovation model. In a constellation of such circumstances, it can be argued that it is significantly easier to implement innovation activities directed towards the products/ services than to achieve sustainable organisation innovation, which needs specific organisational culture and other organisational related elements which are challenging to build and require substantial time and resources.

The identified negative impact of marketing innovation on innovation performance indicates that innovation is unlikely to be beneficial if the market and customers are not prepared to accept the changes in the current situation. This finding also suggests that customers remain within the existing standards and/or norms and push innovative firms into unfavourable competitive positions (Hargadon \& Douglas, 2001). This is strongly supported by the Hofstede Uncertainty Avoidance Index (UAI), 87 for the Republic of North Macedonia. This very high index indicates that people find mechanisms to avoid uncertainty, change is not readily accepted, and a high level of aversion to risk. People maintain rigid beliefs and behaviours and are intolerant of non-traditional behaviours and ideas. To minimise uncertainty, there is a need for strict rules, laws, policies and regulations (Hofstede Insights, 2021). Additionally, the negative effect of marketing innovations may be due to the low Indulgence Versus 
Restraint (IVR) index (35), which shows that the Republic of North Macedonia has a culture of restraint. Abstinent societies tend to have high levels of pessimism.

Also, they do not put much emphasis on free time and control the satisfaction of their desires. Considering that the insurance is perceived as luxury good, people perceive that their actions are limited by social norms and think that enjoyment is somewhat wrong (Hofstede Insights, 2021). However, these interpretations need to be further analysed to empirically determine the impact of the above indices on the negative relationship between marketing innovation and financial performance in insurance companies. Next, the lack of insight into marketing and marketing goals weakens the organisation's ability to perform innovative marketing activities and negatively affects the firm's performance. On the other hand, combining these two factors at a high level improves and strengthens their relationship with marketing innovation.

Another possible explanation for the negative effect of marketing innovations measured by the degree of design renewal of current and/or new products/services through changes in appearance, packaging or shape, without changing their essential technical and functional characteristics, renewal of distribution channels without change of logistics, processes related to the delivery of the product/ service and the renewal of the promotion and pricing techniques of the product/service used to promote current and/or new products/services, on the innovative performance of insurance companies is that superb choice. Higher quality of service results in higher costs. These costs if accompanied by the concept of "marketing myopia", which focuses on meeting the immediate needs of the company and takes into account specific attributes of the product or service while completely ignoring long-term goals such as product quality, needs and satisfaction of the customers, demand, can result in inadequate marketing management and have adverse effects on the survival of other business activities, resulting from the negative consequences of short-term orientation and myopic focus on the manifested demand, which contributes to imitation, lack of distinctive advantage and opportunities.

\section{CONCLUSION}

The research findings enabled the assessment of business activities aimed at implementing innovation and increasing efforts to develop long-term strategies and practices based on encouraging innovation and reconfiguration of organisational resources to improve the competitive advantage and financial performance of insurance companies. Additionally, this study offered theoretical and empirical support for adopting and implementing innovations in the insurance sector.

We examine the literature on innovation and innovation capability and their effect on the financial performance of insurance companies in the Republic of North Macedonia. The primary purpose of this paper was to provide empirical evidence for the links between the degree of innovative capabilities and their impact on the financial performance of companies by systematising existing research and highlighting the main empirical results achieved in this research. A low level of innovative ability can affect the implementation of strategic planning in insurance companies. It can result in designing incorrectly formulated strategies and consequently reduce the financial performance of the company.

The research findings confirmed that higher process innovation capabilities positively affect the profitability of insurance companies. But the lack of skills and abilities is one of the biggest obstacles to implementing innovation in the insurance industry. The insurance industry needs to transform a traditionally risk-averse culture into a culture that encourages experimentation in financial risk mitigation. To achieve this, insurance companies need to use new sources of innovation and fresh access ideas from employees, customers, investors, and partners, which will require progressive leadership from the top management in the organisation.

This research was limited to determining the effects of innovative practices on the financial performance of insurance companies in the Republic of North Macedonia. However, some additional components and variables that may affect this relationship were not included and tested in this study. In this regard, future research could consider such dimensions to expand the research framework 
and increase knowledge about the effects of innovation capabilities in insurance companies. Further research could also consider the concept of green innovation or sustainable innovation, which includes knowledge management and knowledge sharing within organisations. In addition, the research was limited to cross-sectional data used to determine the current state and impact of innovation capabilities on companies' performance. To this end, it is necessary to consider a longitudinal research methodology that should collect data for a certain period. The study was also limited to small number of insurance companies. Therefore, the limited scope limits the generalisation of research findings. It is suggested that future studies in this area improve the generalisation of research by expanding the incentives for more insurance companies at the regional level and validating the model used in this research in other research industries. 


\section{REFERENCES}

Abrunhosa, A., \& Moura,, E. S. (2008). Are TQM principles supporting innovation in the Portuguese footwear industry? Technovation, 4(28), 208-221.

Akman, G., \& Yilmaz, C. (2008). Innovation capability, innovation strategy and market orientation: An empirical analysis in Turkish software industry. International Journal of Innovation Management, 1(12), 69-111.

Alshubiri, F., Jamil, S. A., \& Elheddad, M. (2019). The impact of ICT on financial development: Empirical evidence from the Gulf Cooperation Council countries. International Journal of Engineering Business Management, (11), 1847979019870670.

Ardimento, P., Convertini, V. N., \& Visaggio, G. (2013). Building a knowledge experience base for facilitating innovation. International Journal of E-Services and Mobile Applications, 4(5), 40-49.

Armbruster, H., Bikfalvi, A., Kinkel, S., \& Lay, G. (2008). Organisational innovation: The challenge of measuring non-technical innovation in large-scale surveys. Technovation, 10(28), 644-657.

Bagnoli, C., Dal Mas, F., \& Massaro, M. (2019). The 4th industrial revolution: Business models and evidence from the field. International Journal of E-Services and Mobile Applications, 3(11), 34-47.

Bagozzi, R. P., \& Yi, Y. (1988). On the evaluation of structural equation models. JAMS, (16), 74-94.

Balan, P., \& Lindsay, N. (2010a). Innovation capability: Exploring the factors that make up this construct in the services sector. Paper presented at the 7th AGSE International Entrepreneurship Research Exchange.

Balan, P., \& Lindsay, N. (2010b). Innovation capability And Entrepreneurial Orientation Dimensions for Australian Hotels. Sustainable Tourism Cooperative Research Centre.

Bentler, M. (1990). Comparative fit indexes in structural models. Psychological Bulletin, 2(107), $238-246$. PMID:2320703

Bentler, M., \& Bonett, D. G. (1980). Significance tests and goodness of fit in the analysis of covariance structures. Psychological Bulletin, 3(88), 588-60.

Bigliardi, B., \& Dormio, I. A. (2009). An empirical investigation of innovation determinants in food machineryenterprises. European Journal of Innovation Management, 2(12), 223-242.

Branzei, O., \& Vertinsky, I. (2006). Strategic pathways to product innovation capabilities in SMEs. Journal of Business Venturing, 1(21), 75-105.

Burke, K. (2010). The Impact of Internet and ICT Use among SME Agribusiness Growers and Producers. Journal of Small Business and Entrepreneurship, 2(23), 173-194.

Calantone, R. J., Cavusgil, T., \& Zhao, Y. (2002). Learning Orientation, Firm Innovation Capability, and Firm Performance. Industrial Marketing Management, (31), 515-524.

Chang, S. I., Yen, D. C., Ng, C. S. P., \& Chang, W. T. (2012a). An analysis of IT/IS outsourcing provider selection for small- and medium-sized enterprises in Taiwan. Information \& Management, 5(49), 199-209.

Chang, Y., Linton, J., \& Chen, M. (2012b). Service regime: An empirical analysis of innovation patterns in service firms. Technological Forecasting and Social Change, 10(79), 1569-1582.

Chen, L., \& Xu, Q. (2009, December). The mechanism of innovation capability leveraging via strategy in SMEs. In 2009 IEEE International Conference on Industrial Engineering and Engineering Management (pp. 1057-1061). IEEE.

Corejova, T., Bielik, P., \& Genzorova, T. (2020). Approaches to Project Management in the Process of Digital Transformation in the Company. Proceedings of the ENTRENOVA - ENTerprise REsearch InNOVAtion Conference, Virtual Conference, (6), 531-541.

Danneels, E. (2002). The dynamics of product innovation and firm competences. Strategic Management Journal, 12(23), 1095-1121. 
Deloitte. (2019). Accelerating insurance innovation in the age of InsurTech Insurers of the future will need to evolve and transform. Available at https://www2.deloitte.com/content/dam/Deloitte/us/Documents/financialservices/us-accelerating-insurance-innovation.pdf

Eisenhardt, K. M., \& Martin, J. A. (2000). Dynamic capabilities: What are they? Strategic Management Journal, 10-11(21), 1105-1121.

Evangelista, R., \& Vezzani, A. (2010). The economic impact of technological and organisational innovations. a firm-level analysis. Research Policy, (39), 1253-1263.

Fontana, A. (2011). Innovate We Can! Manajemen Inovasi dan Penciptaan Nilai. Jakarta: Gramedia Widiasarana Indonesia.

Fornell, C., \& Larcker, D. F. (1981). Evaluating Structural Equation Models with Unobservable Variables and Measurement Error. Journal of Marketing Research, 1(18), 39-50.

Frank, M., \& Wallace, C. (2012). The Livelihood Outcomes of ICT Use in Microenterprises: The Case of South Africa. The Electronic Journal on Information Systems in Developing Countries, 1(53), 1-16.

Furjan, M. T., Tomičić-Pupek, K., \& Pihir, I. (2020). Understanding Digital Transformation Initiatives: Case Studies Analysis. Business Systems Research Journal, 1(11), 125-141.

García-Muiña, F. E., \& Navas-López, J. E. (2007). Explaining and measuring success in new business: The effect of technological capabilities on firm results. Technovation, 1(27), 30-46.

Garg, V. K., Walters, A., \& Priem, R. (2003). Chief Executive Scanning Emphases, Environmental Dynamism, and Manufacturing Firm Performance. Strategic Management Journal, 24, 725-744.

Gockov, Gj., \& Kamenjarska, T. (2021). Empirical analysis of the factors determining the profitability of insurance companies in the Republic of North Macedonia. Financial Studies, (25), 1.

Grant, R. M. (1996). Prospering in Dynamically-Competitive Environments: Organisational Capability as Knowledge Integration. Organization Science, 4(7), 375-387.

Gunday, G., Ulusoy, G., Kilic, K., \& Alpkan, L. (2011). Effects of innovation types on firm performance. International Journal of Production Economics, 9(133), 662-676.

Hargadon, A. B., \& Douglas, Y. (2001). When innovations meet institutions: Edison and the design of the electric light. Administrative Science Quarterly, 3(46), 476-501.

Hofstede Insights. (2021). Country comparison. Available at: https://www.hofstede-insights.com/

Howells, J., Tether, B., Gallouj, F., Djellal, F., Gallouj, C., Blind, K., \& Macpherson, A. (2004). Innovation in services: Issues at stake and trends. Available at: https://halshs.archives-ouvertes.fr/halshs-01113600/

Huhtala, J.-P., Sihvonen, A., Frösén, J., Jaakkola, M., \& Tikkanen, H. (2014). Market orientation, innovation capability and business performance: Insights from the global financial crisis. Baltic Journal of Management, 2(9), 134-152.

Hult, G. T., \& Ketchen, D. Jr. (2001). Does Market Orientation Matter? A Test of The Relationship Between Positional Advantage and Perofrmance. Strategic Management Journal, (22), 899-906.

Jerman, A. (2020). The influence of critical factors on business model at a smart factory: A case study. Business Systems Research: International Journal of the Society for Advancing Innovation and Research in Economy, $1(10), 42-52$.

Kalay, F., \& Lynn, G. (2015). The impact of strategic innovation management practices on firm innovation performance. Research Journal of Business and Management, 3(2), 412-429.

Kamal, M., \& Qureshi, S. (2009). An Approach to IT Adoption in Micro-Enterprises: Insights into Development. Proceedings of the Fourth Midwest United States Association for Information Systems Conference.

Kashan, A. J., \& Mohannak, K. (2014). A conceptual analysis of strategic capability development within product innovation projects. Prometheus, 32(2), 161-180. 
Kuusisto, J., \& Meyer, M. (2002). Insights into services and innovation in the knowledge-intensive economy. National Technology Agency TEKES.

Lazonick, W. (2005). The innovative firm. In J. Fagerberg, D. C. Mowery, \& R. R. Nelson (Eds.), The Oxford handbook of innovation (pp. 29-55). Oxford University Press.

Lendel, V., \& Varmus, M. (2014). Evaluation of the innovative business performance. Procedia: Social and Behavioral Sciences, 129, 504-511.

Lichtenthaler, U., \& Lichtenthaler, E. (2009). A capability-based framework for open innovation: Complementing absorptive capacity. Journal of Management Studies, 8(46), 1315-1338.

Lilly, L., \& Juma, D. (2014). Influence of strategic innovation on performance of commercial banks in Kenya: The case of Kenya commercial bank in Nairobi County. European Journal of Business and Management, 1(2), 336-341.

Lin, C. Y., \& Chen, M. Y. (2007). Does Innovation Lead to Performance? An Empirical Study of SMEs in Taiwan. Management Research News, (30), 115-132.

Lupton, N. C., \& Beamish, P. W. (2016). The mutual construction of knowledge transfer and shared context in capability development within the networked MNC. Knowledge Management Research and Practice, 14(1), 150-157.

Marrara, S., Pejić Bach, M., Seljan, S., \& Topalovic, A. (2019). FinTech and SMEs: the Italian case, FinTech as a Disruptive Technology for Financial Institutions. IGI Global.

Martinčević, I., Črnjević, S., \& Klopotan, I. (2020). Fintech Revolution in the Financial Industry, Proceedings of the ENTRENOVA - ENTerprise REsearch InNOVAtion Conference, 6(1), 563-571.

Martinez-Costa, M., \& Martinez-Lorente, A. R. (2008). Does quality management foster or hinder innovation? An empirical study of Spanish companies. Total Quality Management \& Business Excellence, 3(19), $209-221$.

Nunnally, J. C. (1978). Psychometric theory (2nd ed.). McGraw-Hill.

OECD \& Eurostat. (2005). Oslo Manual: Guidelines for Collecting and Interpreting Innovation Data (3rd ed.). OECD.

Oke, A. (2007). Innovation types and innovation management practices in service companies. International Journal of Operations \& Production Management, 6(27), 564-587.

Olson, C. A., \& Schwab, A. (2000). The Performance Effects of Human Resource Practices: The Case of Interclub Networks in Professional Baseball, 1991-1940. Industrial Relations, (39), 553-577.

Özdamar, K. (2017). Scale and test development Structural equation modeling IBM SPSS, IBM SPSS AMOS and MINTAB applied. Nisan Kitabevi.

Pejić Bach, M. (2014). Exploring information and communications technology adoption in enterprises and its impact on innovation performance of european countries. Ekonomicky Casopis, (62), 335-362.

Pejić Bach, M., Spremić, M., \& Suša, V. D. (2018). Integrating Digital Transformation Strategies into Firms: Values, Routes and Best Practice Examples. In Management and Technological Challenges in the Digital Age. Taylor \& Francis Group.

Polder, M., van Leeuwen, G., Mohnen, P., \& Raymond, W. (2010). Product, process and organisational innovation: Drivers, complementarity and productivity effects. Cirano - Scientific Publications. Available at: http://collections.unu.edu/view/UNU:266

Prajogo, D. I., \& Sohal, A. S. (2004). The multidimensionality of TQM practices in determining quality and innovation performance-An empirical examination. Technovation, 6(24), 443-453.

Rajapathirana, R. P., \& Hui, Y. (2018). Relationship between innovation capability, innovation type, and firm performance. Journal of Innovation \& Knowledge, 1(3), 44-55.

Reed, R., Barnes, S. S., \& Jessup, L. (2012). How open innovation affects the drivers of competitive advantage Trading the benefits of IP creation and ownership for free invention. Management Decision, (50), 58-73. 
Reibstein, D. J., Day, G., \& Wind, J. (2009). Guest Editorial: Is Marketing Academe Losing Its Way? Journal of Marketing, (73), 1-3.

Ringle, C. M., Wende, S., \& Becker, J. M. (2015). SmartPLS GmbH. Boenningstedt.

Rosli, M. M., \& Sidek, S. (2013). The Impact of innovation on the performance of small and medium manufacturing enterprises: Evidence from Malaysia. Journal of Innovation Management in Small \& Medium Enterprises, 2013, 1 .

Schaerer, M., Wanner, H., \& Grinyer, C. (2011). Transforming the insurance industry to increase customer relevance. White paper, Cisco Internet Business Solutions Group (IBSG).

Subramanian, A., \& Nilakanta, S. (1996). Organizational innovativeness: Exploring the relationship between organizational determinants of innovation, types of innovations, and measures of organizational performance. Omega, 24(6), 631-647.

Susa Vugec, D., Spremic, M., \& Pejic Bach, M. (2017). IT governance adoption in banking and insurance sector: Longitudinal case study of COBIT use. International Journal of Qualitative Research, 3(11), 691-716.

Taylor, A. (2010). The next generation: Technology adoption and integration through internal competition in new product development. Organization Science, 1(21), 23-41.

Tether, B., Miles, I., Blind, K., Hipp, C., de Liso, N., \& Cainelli, G. (2002). Innovation in the service sector: Analysis of data collected under the Community Innovation Survey (CIS2). ESRC Centre for Research on Innovation and Competition (CRIC). Manchester, UK: CRIC Working Paper, 11.

Thornhill, S. (2006). Knowledge, innovation and firm performance in high- and low-technology regimes. Journal of Business Venturing, 5(21), 687-703.

Tippmann, E., Mangematin, V., \& Scott, P. S. (2013). The two faces of knowledge search: New solutions and capability development. Organization Studies, 12(34), 1869-1901.

Turner, S. F., Mitchell, W., \& Bettis, R. A. (2010). Responding to rivals and complements: How market concentration shapes generational product innovation strategy. Organization Science, 4(21), 854-872.

Vargas, H., Aguilera, E. L., González, A. M., \& Servín, J. L. (2015). The use of ICTs and its relation with the competitiveness of Mexican SMEs. European Scientific Journal, (11), 294-310.

Vicente, M., Abrantes, J. L., \& Teixeira, M. S. (2015). Measuring innovation capability in exporting firms: The INNOVSCALE. International Marketing Review, 1(32), 29-51.

Wallin, A. (2017). Transforming Healthcare through Entrepreneurial Innovations: An Institutional View. International Journal of E-Services and Mobile Applications, 1(9), 1-17.

Wang \& Hsu. (2014). Building exploration and exploitation in the high-tech industry: The role of relationship learning. Technological Forecasting and Social Change, (81), 331-340.

Wu, F., Mahajan, V., \& Balasujbramanian, S. (2003). An Analysis of E-Business Adoption and its Impact on Business Performance. Journal of the Academy of Marketing Science, (31), 425-447.

Yıldız, S., Baştürkb, F., \& Bozc, I. T. (2014). The Effect of Leadership and Innovativeness on Business Performance. Procedia: Social and Behavioral Sciences, 150, 785-793.

Zahra, S. A., \& Neubaum, D. O. (1998). Environmental adversity and the entrepreneurial activities of new ventures. Journal of Developmental Entrepreneurship, 2(3), 123-140. 


\section{APPENDIX}

Table 5. Main indicators of the insurance companies in the Republic of North Macedonia (2020)

\begin{tabular}{|c|c|c|c|c|c|c|}
\hline Company & $\begin{array}{l}\text { Total GWP } \\
\text { in } 000 \text { USD }\end{array}$ & $\begin{array}{c}\text { Share in } \\
\text { the total } \\
\text { premium }\end{array}$ & $\begin{array}{l}\text { Number of } \\
\text { employees }\end{array}$ & $\begin{array}{c}\text { Domestic } \\
\text { capital } \\
\text { share } \%\end{array}$ & $\begin{array}{c}\text { Foreign } \\
\text { capital } \\
\text { share \% }\end{array}$ & $\begin{array}{c}\text { Liquidated } \\
\text { damages in } 000 \\
\text { USD }\end{array}$ \\
\hline $\begin{array}{l}\text { Macedonia } \\
\text { insurance }\end{array}$ & 17045 & 8,57 & 147 & 5,74 & 94,26 & 7026 \\
\hline Triglav & 24330 & 12,24 & 230 & 19,06 & 80,94 & 11059 \\
\hline Euroins & 14361 & 7,22 & 115 & 0,57 & 99,44 & 7017 \\
\hline Sava & 16760 & 8,43 & 232 & 7,4 & 92,6 & 7344 \\
\hline Winner & 14068 & 7,07 & 166 & 0,00 & 100,00 & 6464 \\
\hline Eurolink & 19035 & 9,57 & 200 & 0,00 & 100,00 & 7374 \\
\hline Grawe non-life & 5270 & 2,65 & 75 & 0,00 & 100,00 & 2972 \\
\hline Uniqa & 16348 & 8,22 & 138 & 0,00 & 100,00 & 6272 \\
\hline $\begin{array}{l}\text { Insurance } \\
\text { Policy }\end{array}$ & 11911 & 5,99 & 148 & 95,56 & 4,44 & 5133 \\
\hline Halk & 16233 & 8,16 & 135 & 0,00 & 100,00 & 6043 \\
\hline Croatia & 9102 & 4,58 & 118 & 0,00 & 100,00 & 3790 \\
\hline Croatia life & 12930 & 6,50 & 72 & 5,00 & 95,00 & 4695 \\
\hline Grawe & 10558 & 5,31 & 16 & 0,00 & 100,00 & 2586 \\
\hline Winner life & 6038 & 3,04 & 26 & 0,00 & 100,00 & 648 \\
\hline Uniqa life & 3609 & 1,81 & 20 & 0,00 & 100,00 & 428 \\
\hline Triglav life & 1247 & 0,63 & 36 & 0,00 & 100,00 & 271 \\
\hline TOTAL & 198845 & 100,00 & 1874 & & & 79122 \\
\hline
\end{tabular}

${ }^{*}$ The total GWP and the liquidated and ascertained damages were converted according to the middle exchange rate of MKD published by the National Bank of Republic of North Macedonia. Source: National Insurance Bureau - Insurance Bulletin (2020). 
Table 6. Variable measurement

\begin{tabular}{|c|c|}
\hline Variable & Variable measure \\
\hline $\begin{array}{l}\text { Innovation } \\
\text { Capability (IC) }\end{array}$ & $\begin{array}{l}\text { IC1: Organisational culture } \\
\text { IC2: Using knowledge from different sources } \\
\text { IC3: Involvement of employees and customers } \\
\text { Source: Adapted from Rajapathirana \& Hui (2018), Gunday et al. (2011), Huthala et al. (2014) }\end{array}$ \\
\hline $\begin{array}{l}\text { Product } \\
\text { innovation (PRI) }\end{array}$ & $\begin{array}{l}\text { PRI1: Increasing the quality of production in the components or materials of current products / } \\
\text { services } \\
\text { PRI2: Reduction of production costs of components or materials of current products / services } \\
\text { PRI3: Development of innovations in current products / services that lead to improved customer } \\
\text { satisfaction and access } \\
\text { Source: Adapted from Rajapathirana \& Hui (2018), Gunday et al. (2011) }\end{array}$ \\
\hline $\begin{array}{l}\text { Process } \\
\text { innovation }(\mathrm{PCI})\end{array}$ & $\begin{array}{l}\text { PCI1: Identify and eliminate activities that do not add value in the process of selling and paying } \\
\text { damages } \\
\text { PCI2: Reduce the price and / or increase the speed of service delivery } \\
\text { PCI3: Increasing the quality of the sales process } \\
\text { Source: Adapted from Rajapathirana \& Hui (2018), Gunday et al. (2011) }\end{array}$ \\
\hline $\begin{array}{l}\text { Organizational } \\
\text { innovation }(\mathrm{OI})\end{array}$ & $\begin{array}{l}\text { OI1: Renewal of the organisational structure for easier formation of strategic partnerships and } \\
\text { long-term business collaborations, facilitation of teamwork and coordination between different } \\
\text { departments } \\
\text { OI2: Update on quality management systems, human resources and information system management } \\
\text { and information sharing practices } \\
\text { OI3: Renewal of routines, procedures and processes } \\
\text { Source: Adapted from Rajapathirana \& Hui (2018), Gunday et al. (2011) }\end{array}$ \\
\hline $\begin{array}{l}\text { Market } \\
\text { innovation }(\mathrm{MI})\end{array}$ & $\begin{array}{l}\text { MI1: Renovation of the design of current and / or new products / services through changes in } \\
\text { appearance, packaging or shape, without changing their basic technical and functional characteristics } \\
\text { MI2: Renewal of distribution channels without change of logistics, processes related to the delivery } \\
\text { of the product / service } \\
\text { MI3: Update of promotion and pricing techniques for the product / service used to promote current } \\
\text { and / or new products / services } \\
\text { Source: Adapted from Rajapathirana \& Hui (2018), Gunday et al. (2011) }\end{array}$ \\
\hline $\begin{array}{l}\text { Innovation } \\
\text { performance } \\
\text { (IP) }\end{array}$ & $\begin{array}{l}\text { IP1: Ability to introduce new products and services to the market before competitors } \\
\text { IP2: Introduced innovations in work processes and methods } \\
\text { IP3: Improved quality of new products and services } \\
\text { Source: Adapted from Gunday et al. (2011) }\end{array}$ \\
\hline $\begin{array}{l}\text { Financial } \\
\text { performance } \\
\text { (FP) }\end{array}$ & $\begin{array}{l}\text { ROA } \\
\text { ROE } \\
\text { Source: Adapted from Rajapathirana \& Hui (2018), Gunday et al. (2011) }\end{array}$ \\
\hline
\end{tabular}


Tanja Kamenjarska graduated at the Faculty of Economics, Ss. Cyril and Methodius University in the Republic of North Macedonia. Her fields of research interest are management of information systems and innovation, financial markets and institutions, and quantitative economics.

Mario Spremić is a full professor at the Department of Informatics, Faculty of Economics and Business (FEB), University of Zagreb, Croatia, and a guest lecturer at several international institutions (such as Imperial College London). He holds a B.Sc. in mathematics, and M.Sc. in IT management and Ph.D. in business, all from the University of Zagreb. He joined FEB (Zagreb), in 2000, with previous corporate experience as a computer programmer and project manager. Mario has participated in executive education programs at MIT Sloan School of Management and EFMD Executive Academy. He has broad experience in international accreditation of higher education institutions (EQUIS, AACSB, EPAS peer-review). His main research interest areas are digital computing, the digital economy, ICT governance cyber security, and IT auditing.

Ivan Miloloža graduated from the Faculty of Economics in Zagreb. He lived and worked abroad in the period 1983rd to 1986th (Argentina and Netherland). Since 1986 he has been employed in the company Munja, the only Croatian battery producer, where he held almost all management functions and is currently Chairman of the Board (since 1999). He held many social functions in various government bodies, associations and banks, and he was a participant and a guest lecturer at numerous national and international Conferences. He received his doctorate in 2015 at the Faculty of Economics in Osijek. Currently, he is an associate professor and Vide Dean at Faculty for Dental Medicine \& Health. 